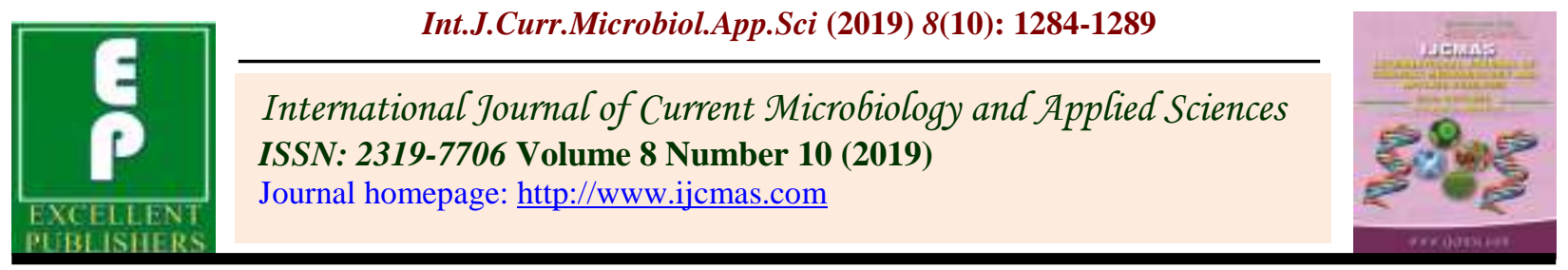

\title{
In Vitro Evaluation of Some Selected Fungicides against Coconut Leaf Spot Caused by Pestalotia palmarum (Cooke) in Bastar Plateau of Chhattisgarh
}

\author{
Vandana Chadar*, R. R. Bhanwar, Rajesh Kumar Patel, P. K. Salam and Beena Singh
}

Department of Plant Pathology, AICRP on Rape Seed \& Musturd, S. G. College of Agriculture and Research Station, Jagdalpur, IGKV, Chhattisgarh, 494001, India

*Corresponding author

\section{A B S T R A C T}

\begin{tabular}{|c|}
\hline Keywords \\
\hline $\begin{array}{l}\text { Coconut leaf spot, } \\
\text { Fungicides, In vitro, } \\
\text { Pestalotia } \\
\text { palmarum, } \\
\text { Poisoned food } \\
\text { technique }\end{array}$ \\
\hline Article Info \\
\hline $\begin{array}{l}\text { Accepted: } \\
\text { 12 September } 2019 \\
\text { Available Online: } \\
10 \text { October } 2019\end{array}$ \\
\hline
\end{tabular}

\section{Keymords}

Coconut leaf spot, Fungicides, In vitro, technique

Accepted: Available Online: 10 October 2019

\section{Introduction}

Coconut is (Cocus nucifera Linn.) the most important perennial fruit plant in the world belonging to the family Arecaceae (Palmaceae). Coconut palms are successfully grown in the tropics and hence referred to as 'King of the tropical palms'. The coconut tree, C. nucifera, has a long history of providing man with useful materials for his daily life. It is one of the ten most useful trees in the world. From top to root, every part of the coconut tree is in a way or another essential in farmers" households. The growing tip of the palm makes a tasty treat, the "millionaire's salad"; the sheath protecting unopened flowers is often used to fashion shoes, caps and even a kind of pressed helmet for soldiers ${ }^{1}$. Coconut cultivation in India dates back to more than 3,000 years and the plant survived all along 
without major pest damage. It is conceivable that the coconut mite, Aceria guerreronis, existed in India since the early 1960 even before its first report in Mexico when chemical pesticides were sparingly used, allowing the local natural enemies to keep it under control ${ }^{2}$.

The importance of the palm lies in fact that not only does it supply food, drink and shelter but it also provides raw materials for a number of industries ${ }^{3}$. In Kerala, coconut occupies first place in the area under cultivation of crops and Kerala ranks top in area (788000 ha) and production (3992 million nuts) of coconut in India ${ }^{4}$.

\section{Materials and Methods}

\section{Collection of sample}

Diseased leaves of Coconut with typical leaf spot symptoms were collected from AICRP on Palms Research field of SGCARS, Jagdalpur (C.G.).

\section{Isolation of the fungus}

The fungus was isolated from the infected leaf of coconut following tissue planting technique ${ }^{5}$.

The infected diseased samples along with healthy tissues were cut into small pieces and surface sterilized by dipping in $0.1 \%$ sodium hypochloride $(\mathrm{NaOCl})$ solution for two minutes. $\mathrm{NaOCl}$ on the surface of the leaf pieces was decanted by soaking with sterilized blotting paper.

The cut pieces were then placed onto sterilized potato dextrose agar (PDA) in glass petridishes $(20 \mathrm{ml} /$ petridish $)$ and incubated in an incubator at $27 \pm 1^{\circ} \mathrm{C}$ until mycelium formation. The hyphal tips were transferred onto PDA plate after growing the mycelium.

\section{Identification of fungus}

The fungus was then identified on the basis the morphological of characteristics with the help of identifying key book ${ }^{6}$.

\section{Purification}

To obtain pure culture of the pathogen, the hyphal tips were transferred aseptically onto PDA plate by using the flame sterilized tip of an inoculation needle. The plate was incubated at room temperature for seven days (Fig. 1).

\section{Multiplication of $\boldsymbol{P}$. palmarum}

PDA was poured in sterilized petridishes, 25 $\mathrm{ml}$ in each. After solidification, the plates were inoculated by placing $5 \mathrm{~mm}$ discs of three days old PDA culture of $P$. palmarum. The discs were cut with flame sterilized cork borer $(5 \mathrm{~mm}$ diameter). The inoculated petridishes were kept in the growth chamber at a temperature of $28 \pm 1^{\circ} \mathrm{C}$ for few days. All the works were undertaken under the laminar air flow cabinet.

\section{Different fungicides used in this experiment}

Different fungicides were evaluated in in vitro condition against $P$. palmarum following poison food technique ${ }^{7}$. All the fungicides were tested at recommended by adopting poisoned food technique (Table 1).

The test pathogen was grown on PDA medium in Petri plates for seven days prior to setting up of experiment. The required fungicidal suspension was added to the melted PDA medium to obtain the desired concentration on the basis of active ingredients present in the chemical.

$20 \mathrm{ml}$ of poisoned medium was poured in each Petri plate. Suitable checks were maintained without addition of fungicides. A mycelial 
disc of five mm diameter was taken from the periphery of 7 days old colony and placed in the centre and incubated at $28 \pm 2^{\circ} \mathrm{C}$ for full growth of the fungus. Three replications were maintained for each treatment. The radial growth of the colony was measured in two directions and average was recorded. Per cent inhibition was recorded by using the formula as under ${ }^{8}$ :

$\mathrm{PI}=[(\mathrm{C}-\mathrm{T}) / \mathrm{C}] \times 100$

Where,

$\mathrm{PI}=$ Per cent inhibition

$\mathrm{C}=$ Growth in control

$\mathrm{T}=$ Growth in treatment

\section{Results and Discussion}

Efficacy of 13 fungicides viz. Carbendazim 12 +Mancozeb 63 WP, Mancozeb $75 \%$ WP, Hexaconazole 5\%, Carbendazim $50 \%$ WP,
Chlorothionil75 \%WP, Propiconazole $25 \%$ EC, Carbendazim 16 + Hexaconazole 4\% SC, Tricyclazole $75 \%$ WP, Validamycin, Tabuconazole $10+$ Sulpher $65 \%$ WG, Tricyclazole + Tabuconazole $36 \%$ SC, Isoprothiolane $40 \%$ and Propineb $70 \mathrm{WP}$ were evaluated against coconut leaf spot $(P$. palmerum) adopting poisoned food technique. Observations of the radial growth of the pathogen were recorded after 7 day after inoculation. The percent inhibition of the pathogen over control was calculated and presented in Table 2, Figure 2 and Chart. 1.

The superiority in controlling the inhibition of pathogen was managed by Carbendazim 12 +Mancozeb 63 WP, Hexaconazole $5 \%$, Carbendazim $50 \%$ WP, Chlorothionil 75 $\% \mathrm{WP}$, Propiconazole $25 \%$ EC and Carbendazim $16+$ Hexaconazole $4 \%$ SC inhibited the growth of $P$. palmarum totally.

Table.1 The fungicides used in the experiment are

\begin{tabular}{|c|c|c|}
\hline Treatments & Name of the fungicides & Doses (Per cent) \\
\hline $\mathbf{T}_{1}$ & Carbendazim 12 +Mancozeb $63 \mathrm{WP}$ & 0.1 \\
\hline $\mathbf{T}_{2}$ & Mancozeb $75 \% \mathrm{WP}$ & 0.1 \\
\hline $\mathbf{T}_{\mathbf{3}}$ & Hexaconazole $5 \%$ & 0.1 \\
\hline $\mathbf{T}_{4}$ & Carbendazim $50 \% \mathrm{WP}$ & 0.1 \\
\hline $\mathbf{T}_{5}$ & Chlorothionil75 \% WP & 0.1 \\
\hline $\mathbf{T}_{6}$ & Propiconazole $25 \% \mathrm{EC}$ & 0.1 \\
\hline $\mathbf{T}_{7}$ & Carbendazim $16+$ Hexaconazole $4 \%$ SC & 0.1 \\
\hline $\mathbf{T}_{8}$ & Tricyclazole $75 \% \mathrm{WP}$ & 0.1 \\
\hline $\mathbf{T}_{9}$ & Validamycin & 0.1 \\
\hline $\mathbf{T}_{10}$ & Tabuconazole $10+$ Sulpher $65 \%$ WG & 0.1 \\
\hline $\mathbf{T}_{11}$ & Tricyclazole + Tabuconazole $36 \%$ SC & 0.1 \\
\hline $\mathbf{T}_{12}$ & Isoprothiolane $40 \%$ & 0.1 \\
\hline $\mathbf{T}_{13}$ & Propineb $70 \mathrm{WP}$ & 0.1 \\
\hline
\end{tabular}


Table.2 Percent inhibition of the radial growth of the pathogen of coconut leaf spot in in-vitro

\begin{tabular}{|c|c|c|}
\hline Treatment & $\begin{array}{c}\text { Mean of radial colony } \\
\text { growth }(\mathbf{m m}) \text { of pathogen }\end{array}$ & $\begin{array}{c}\text { Per cent Inhibition of } \\
\text { growth of the pathogen } \\
\text { over control }\end{array}$ \\
\hline $\mathbf{T}_{\mathbf{1}}$ & 0 & 100 \\
\hline $\mathbf{T}_{\mathbf{2}}$ & 6.6 & 60.24 \\
\hline $\mathbf{T}_{\mathbf{3}}$ & 0 & 100 \\
\hline $\mathbf{T}_{\mathbf{4}}$ & 0 & 100 \\
\hline $\mathbf{T}_{\mathbf{5}}$ & 0 & 100 \\
\hline $\mathbf{T}_{\mathbf{6}}$ & 0 & 100 \\
\hline $\mathbf{T}_{\mathbf{7}}$ & 0 & 100 \\
\hline $\mathbf{T}_{\mathbf{8}}$ & 5.3 & 68.07 \\
\hline $\mathbf{T}_{\mathbf{9}}$ & 12.6 & 24.09 \\
\hline $\mathbf{T}_{\mathbf{1 0}}$ & 11 & 33.73 \\
\hline $\mathbf{T}_{\mathbf{1 1}}$ & 6 & 63.85 \\
\hline $\mathbf{T}_{\mathbf{1 2}}$ & 6 & 63.85 \\
\hline $\mathbf{T}_{\mathbf{1 3}}$ & 12.3 & 25.90 \\
\hline Control & $\mathbf{1 6 . 6}$ & - \\
\hline C.D. $\mathbf{a t} \mathbf{5} \%$ & $\mathbf{0 . 9 7}$ & - \\
\hline S.E.(m) \pm & $\mathbf{0 . 3 3}$ & - \\
\hline
\end{tabular}

Fig.1 Pure culture of $P$. palmarum Fig.2 Effect of different fungicides on $P$. palmarum246
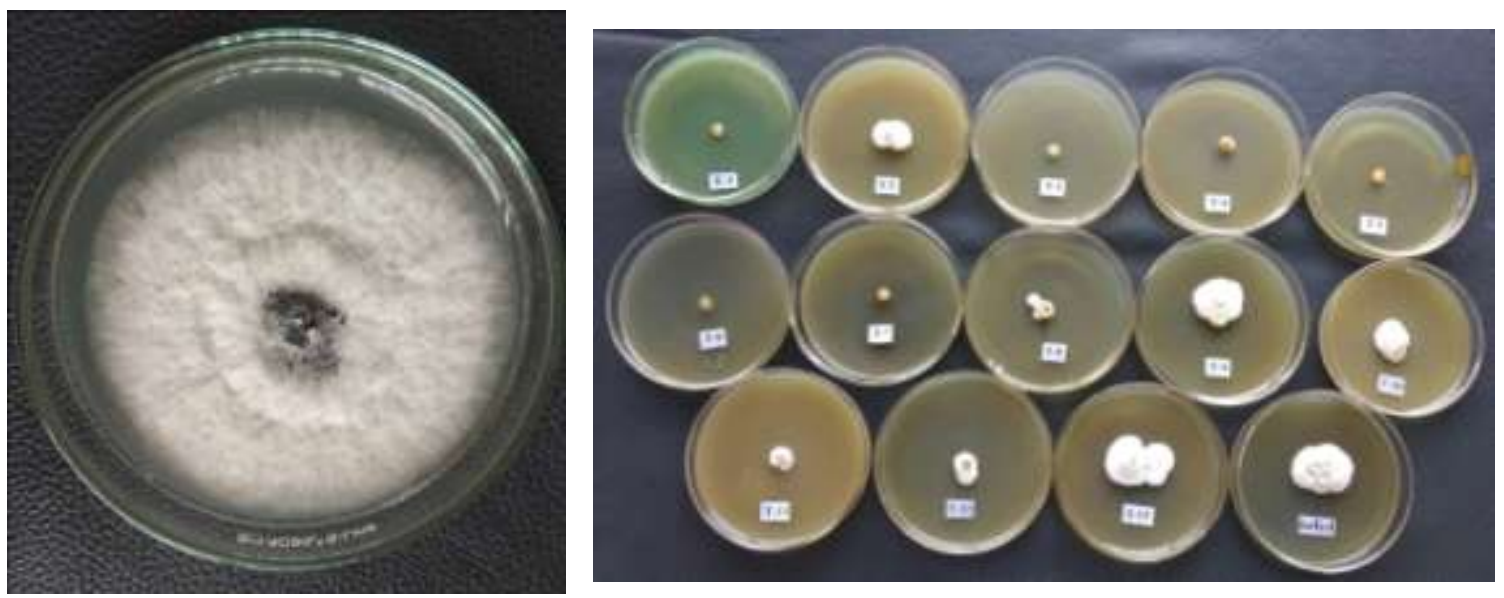
Chart.1 Percent inhibition of the radial growth of the pathogen of coconut leaf spot in in-vitro

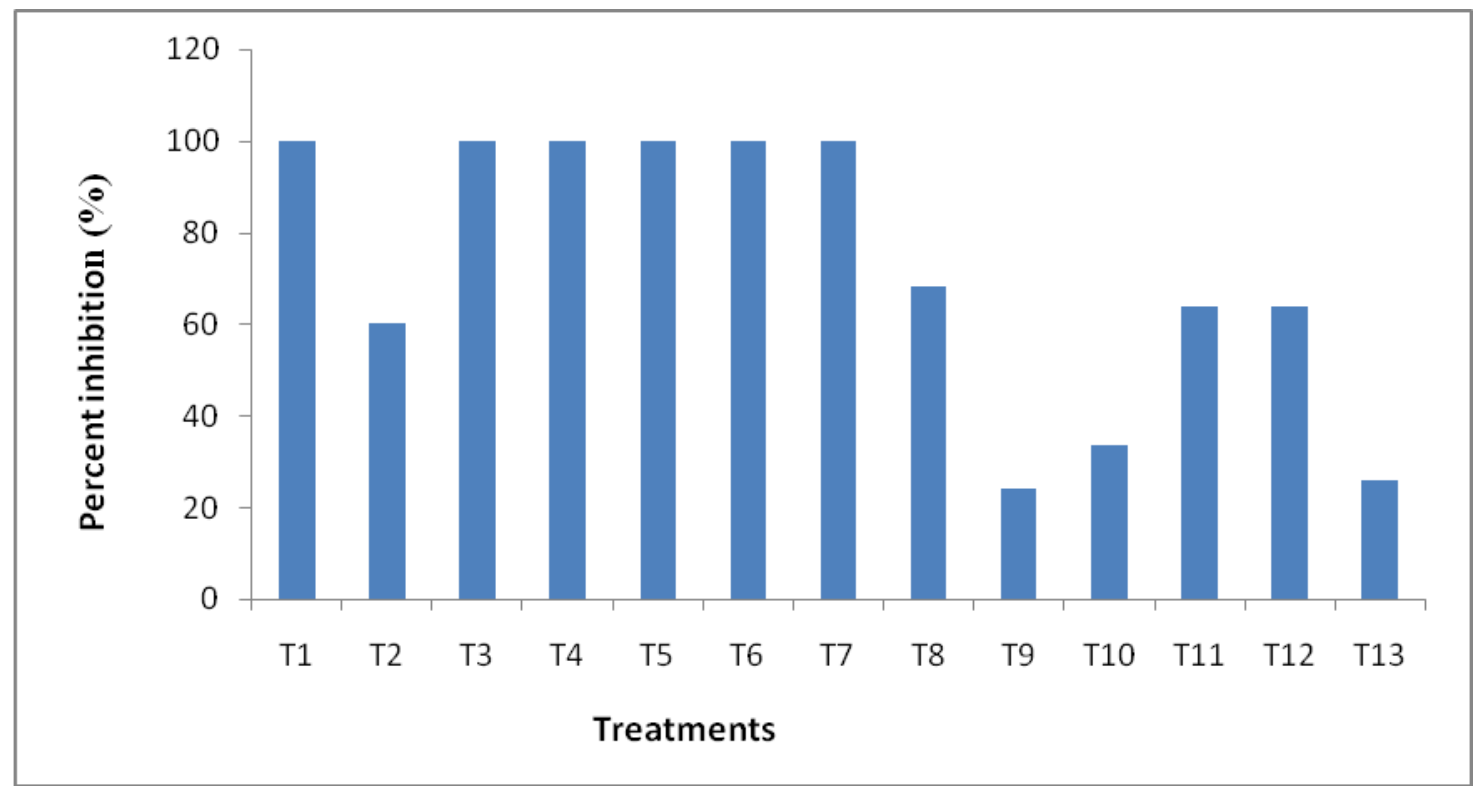

No growth was found at given concentration. The Tricyclazole $75 \% \mathrm{WP}$, Tricyclazole + Tabuconazole $36 \%$ SC, Isoprothiolane $40 \%$ and Mancozeb $75 \%$ WP fungicides were also inhibit the fungus up to $68.07,63.85,63.85$ and 60.24 per cent, respectively.

Whereas, Tabuconazole $10+$ Sulpher $65 \%$ WG, Propineb $70 \mathrm{WP}$ and Validamycin inhibits the lesser up to 33.73, 25.9 and 24.09 per cent, respectively (Table 2). Carbandazim was most effective against the P. Palmarum ${ }^{9}$ while, Propiconazole was found very effective in the inhibition of $P$. palmarum in the study ${ }^{10}$. Mancozeb found as the most effective but in present study it was effective only ${ }^{11 \text { and } 12}$.

\section{Acknowledgement}

The author is grateful to acknowledge the AICRP on Rapeseed \& Mustard, Jagdalpur and S. G. College of Agriculture and Research Station, Jagdalpur for proving necessary amenities during entire course of work.

\section{References}

1. Foale M. 2003. The coconut odyssey: the bounteous possibilities of the tree of life. Australian Centre for International Agricultural Research, 101: 132.

2. Haq MA. 1999. Coconut mite threat in Kerala. J Acaro 14: 58-63.

3. BBS. 2005. Statistical Year Book. Bangladesh Bureau of Statistics. Ministry of Planning, Government of the Peoples Republic of Bangladesh.

4. Kumar B, Mistry NC, Singh B and Gandhi CP. 2011. Indian Horticulture Database 2010. National Horticulture Board, Ministry of Agriculture, Government of India, Gurgaon. 262.

5. Tuite. 1969 Plant Pathological method; Fungi and Bacteria. Burgess Publishing Company Inneapolis, Minn, USA.

6. Barnett HL and Hunter BB. 1972. Illustrated Genera of imperfect Fungi. Burgess Publishing Company.

7. Dhingra, OD and Sinclair JB.1985. Basic Plant Pathology Methods. CRC Press, Boca Raton, USA. 
8. Vincent JH. 1947. Distortion of Fungal Hyphae in the Presence of Certain Inhibitors. Nature, 15: 850.

9. Rahman S, Adhikary SK, Sultana S, Yesmin S and Jahan N. 2013. In vitro Evaluation of Some Selected Fungicides against Pestalotia palmarum (Cooke.) Causal Agent of Grey Leaf Spot of Coconut. J Plant Pathol Microb 4: 197 doi:10.4172/2157-7471.1000197.

10. Parveena R and Kachapur MR. 2002. In vitro evaluation of fungicides against grey leaf spot of coconut caused by Pestalotia palmarum Cooke. Conference paper: Proceedings of the 15th Plantation Crops Symposium Placrosym XV, Mysore, India 570-571.

11. Sanjay R, Ponmurugan P and Baby UI. 2006. Evaluation of fungicides and biocontrol agents against grey blight disease of tea in the field. J Crop Prot 27: 689-692.

12. Sharma. 1987. Evaluation on six fungicides against leaf disease of Chicku (Achras sapota) caused by Pestalotia Sapotae 34: 243-246.

\section{How to cite this article:}

Vandana Chadar, R. R. Bhanwar, Rajesh Kumar Patel, P. K. Salam and Beena Singh. 2019. In Vitro Evaluation of Some Selected Fungicides against Coconut Leaf Spot Caused by Pestalotia palmarum (Cooke) in Bastar Plateau of Chhattisgarh. Int.J.Curr.Microbiol.App.Sci. 8(10): 1284-1289. doi: https://doi.org/10.20546/ijcmas.2019.810.151 